\title{
Colonização japonesa, história econômica e desenvolvimento regional do Estado do Pará
}

Japanese colonization, economic history and regional development of the

\section{State of Pará}

Armando Wilson Tafner Jr. - Mestre em Planejamento do Desenvolvimento pelo Núcleo de Altos Estudos Amazônicos (NAEA/UFPA) e doutorando do Programa de Pós-Graduação em Desenvolvimento Sustentável do Trópico Úmido (NAEA/UFPA). E-mail: armandowilson@ hotmail.com

Fábio Carlos da Silva - Doutor em História Econômica pela Universidade de São Paulo. Professor Associado do Núcleo de Altos Estudos Amazônicos (NAEA/UFPA). E-mail: fcsilva@ufpa.br

\section{Resumo}

Este artigo apresenta um panorama geral da história econômica das mesorregiões do estado do Pará, principalmente ao longo do século $\mathrm{XX}$, analisando-se também os fatos históricos e econômicos mais relevantes que caracterizam a trajetória dos 70 anos dos japoneses na região nordeste do Pará, a mais atrasada do estado. Nessa região, os japoneses conseguiram lançar as bases e consolidar o empreendimento associativo de pequenos produtores agrícolas mais bem sucedido da Amazônia, a atual Cooperativa Agrícola Mista de Tomé-Açu, que se constitui no único arranjo produtivo local efetivo em território paraense.

\begin{abstract}
This paper presents a general approach of the twentieth century economic history of the great regions of the state of Para, Brazil. It also analyses the more expressive events which has been occurred during the 70 years of the Japanese immigration to northern of Para, the poorest region of that state. In that region, the Japanese undertook the more successful collective entrepreneurial of small agriculture producers in Amazon, the Cooperativa Agrícola Mista de Tomé-Açu, which is the only effective local productive arrangement in Para.
\end{abstract}

\section{Palavras-chave}

Amazônia. História econômica regional. Imigração japonesa. Associativismo.

\section{Keywords}

Amazon. Regional economic history. Japanese immigration. Associativism. 


\section{INTRODUÇÃO}

O estado do Pará, segundo maior estado brasileiro em dimensão territorial e detentor do maior PIB da Amazônia, paradoxalmente é o que possui as piores condições sociais da Região Norte e um dos piores do Brasil. A colonização do território paraense, desde o período colonial até o presente, continua mantendo, na sua essência, as mesmas características do período inicial da colonização portuguesa na Amazônia, isto é, extrativismo predatório dos recursos naturais, sem agregação de valor e transferência da riqueza gerada no Pará para agentes externos.

Essa característica da formação econômica paraense, entre outros fatores, pode ser explicada pela ausência de um ambiente cultural na Amazônia em geral, e no Pará, em particular, que contribua para o surgimento de empreendimentos associativos que possam romper com esse cenário de pobreza, desemprego, baixa escolaridade e péssimas condições de vida da população que habita o território paraense.

Este artigo apresenta os contornos gerais da colonização japonesa na meso-região nordeste paraense, a mais atrasada do Estado, que, paradoxalmente, é a que abriga o empreendimento produtivo coletivo mais bem sucedido do Pará, a Cooperativa Agrícola Mista de Tomé-Açu (CAMTA) - obra da colonização japonesa no século XX na Amazônia.

O texto está organizado, além da introdução e das considerações finais, em três sessões. A sessão 1 analisa, em linhas gerais, a história econômica das macrorregiões paraenses como elemento de contextualização da colonização japonesa que ocorreu na região nordeste paraense. A sessão 2 aborda a história econômica do único empreendimento de cunho associativo bem sucedido no nordeste paraense, a produção de alimentos organizada pelos imigrantes japoneses no Pará, através da CAMTA, e a sessão 3 resume as principais contribuições da colonização japonesa para o desenvolvimento regional do Pará.

\section{HISTÓRIA ECONÔMICA DO PARÁ E SUAS MACRORREGIÕES}

A formação econômica das três macrorregiões paraenses - oeste, nordeste e sudeste (Figura 1) está fortemente ligada aos meios de transporte de mercadorias e pessoas utilizados ao longo da história da humanidade na idade moderna.
No território do nordeste paraense, atualmente constituído pelas mesorregiões Metropolitana de Belém, Marajó e Nordeste propriamente dita, foi onde teve início a colonização portuguesa na Amazônia, graças à utilização das caravelas e naus que os portugueses desenvolveram para expandir seus negócios comerciais na transição do feudalismo para o capitalismo na Europa. Foi também nessa região que há oitenta anos teve início a colonização japonesa na Amazônia.

Os fortes militares e as missões de catequese católicas deram início ao processo de colonização do Pará. Belém foi o primeiro núcleo de povoamento por europeus e onde se estabeleceu uma dinâmica mais consistente do Estado português para apoiar a ocupação do interior amazônico. Singrando os principais rios da bacia amazônica a partir de sua foz, as regiões oeste e nordeste do Pará foram as primeiras a terem seus recursos naturais explorados pelos colonizadores lusitanos. Na região oeste, para reprimir holandeses e ingleses que haviam se estabelecido nas proximidades da foz do rio Xingu e no Marajó, os portugueses subiram o Amazonas e fundaram vários fortes militares às margens do grande rio, que deram origem às principais cidades da região: entre elas Gurupá, Óbidos e Santarém.

No nordeste do Pará, buscando caminho terrestre alternativo entre Belém e São Luís, fundou-se Bragança, em 1634. A exploração da canela, especiaria muito apreciada na Europa no século XVII, levou à fundação de Cametá, em 1637, no Baixo Tocantins. O barco a vapor, que foi introduzido na Amazônia por Mauá em 1852, ligou Belém a Manaus e aumentou o comércio das drogas do sertão da região oeste do estado, que desde finais do século XVII, teve em Santarém o principal núcleo de colonização da região, servindo como entreposto comercial da economia das drogas do sertão regionais (cacau, cravo, salsaparrilha e principalmente a borracha, no final do século XIX).

O sudeste paraense, devido às dificuldades de navegação do rio Tocantins a montante da atual cidade de Tucuruí, permaneceu quase que à margem desse processo de exploração econômica até o século XX. 

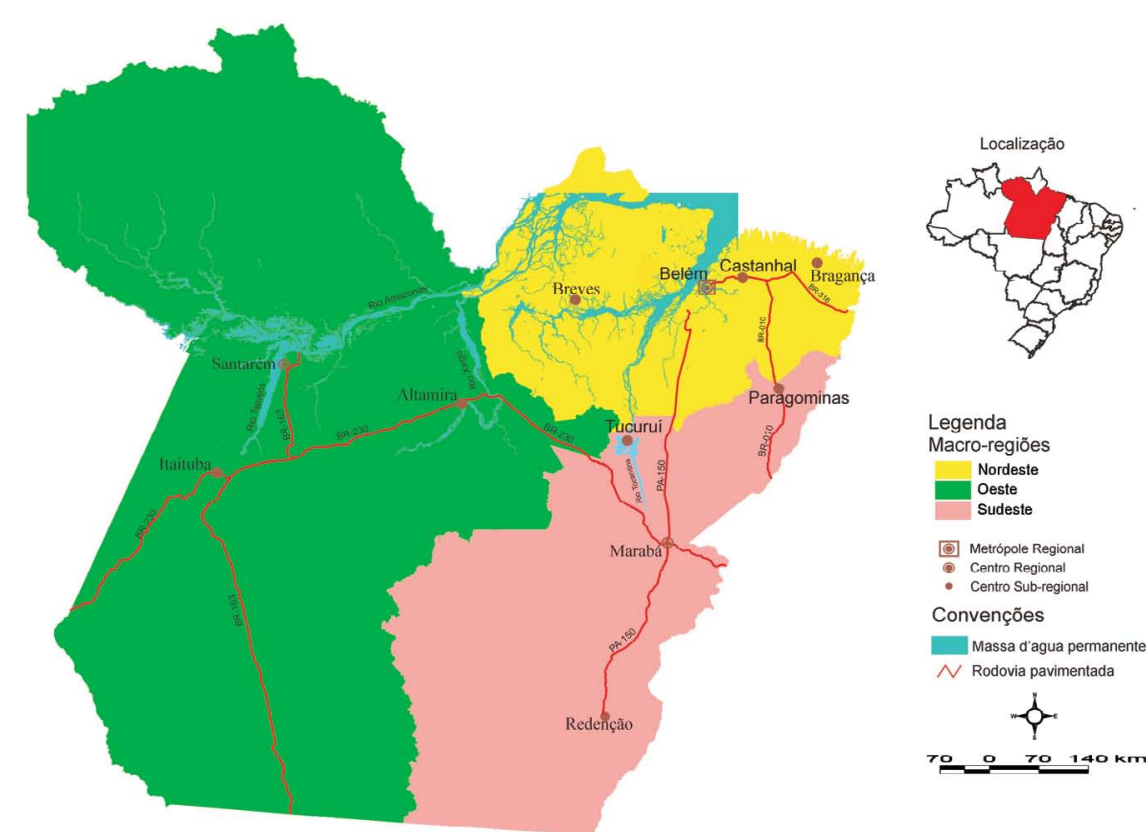

Figura 1. Mapa de localização das macrorregiões oeste, nordeste e sudeste paraenses. Fonte: IBGE

Embora esse processo de colonização no Pará durante os períodos colonial e imperial possa contribuir para explicar em parte os fundamentos da formação da região pioneira, principalmente de parcela do nordeste paraense, como Belém, capital do estado e metrópole regional do Norte brasileiro, Marajó e Baixo Tocantins, ela não é suficiente para se entender a formação econômica da maior parte do território que hoje compõe o estado do Pará.

Isso porque apesar da ocupação demográfica e econômica ter tido início, como vimos, com a fundação do forte militar que deu origem à cidade de Belém, em janeiro de 1616, esse processo somente engendra diferenças regionais internas a partir do final do século XIX, quando a parte norte do leste paraense, diretamente polarizada por Belém, passa a ser ocupada por migrantes estrangeiros e nordestinos, em decorrência da colonização oficial do governo estadual que planejou a ocupação da região para ser um polo agrícola de abastecimento da capital do estado. Isso ocorreu porque a maioria da população passou a se dedicar à extração da borracha, causando crise no abastecimento de gêneros alimentícios nos núcleos urbanos, principalmente em Belém.
A construção da Estrada de Ferro Belém-Bragança, iniciada em 1883 e concluída em 1908, ligou Belém à cidade de Bragança, núcleo de povoamento dos mais antigos do estado, que desde a sua fundação, em 1634, em função do isolamento e presença de índios hostis, permaneceu estagnada econômica e socialmente até a construção da via férrea, que originalmente previa ligar Belém a São Luís. A colonização da bragantina, nome com que passou a ser designada toda a região leste do Pará, baseada em política agrícola de ocupação de pequenos lotes de 25 hectares, em média, deu origem a um intenso processo de ocupação demográfica e desmatamento da floresta que ali existia, principalmente por migrantes nordestinos.

No sul do Pará, além das correntes migratórias mais expressivas formadas por nordestinos com baixa escolaridade e desprovidos de recursos materiais e conhecimento mínimo para enfrentar situações de adversidade, também ocorreu, após a abertura da rodovia Belém-Brasilia, um fluxo migratório de pessoas e capitais do Sul para o Norte, quando, além de agricultores do sul, descendentes de alemães e italianos, também se deslocou para a região o grande capital baseado em São Paulo, que provocou alterações significativas no padrão de vida local, com grandes investimentos na pecuária e exploração florestal e mineral da região.

No nordeste paraense, região de ocupação mais antiga, prevaleceram as frentes migratórias de agricultores nordestinos castigados pela seca, com baixa escolaridade e baixa cultura associativa, que não conseguiram implantar empreendimentos capazes de aumentar o padrão de vida regional. A única e expressiva exceção foi a atividade econômica desenvolvida há setenta anos pelos imigrantes japoneses que se fixaram na região do vale do rio Acará, atual município de Tomé-Açu (Figura 2), e conseguiram lançar as bases e consolidar o empreendimento associativo de pequenos produtores agrícolas mais bem sucedido da Amazônia, a atual Cooperativa Agrícola Mista de Tomé-Açu.

A seguir, apresentam-se os fatos históricos e econômicos mais relevantes que caracterizam a trajetória dos 70 anos dos japoneses nessa região da Amazônia, que, paradoxalmente, como vimos, insere-se na região nordeste do Pará, a mais atrasada e com piores condições de vida do estado. Trata-se, na verdade, do único arranjo produtivo local efetivo em território paraense. 


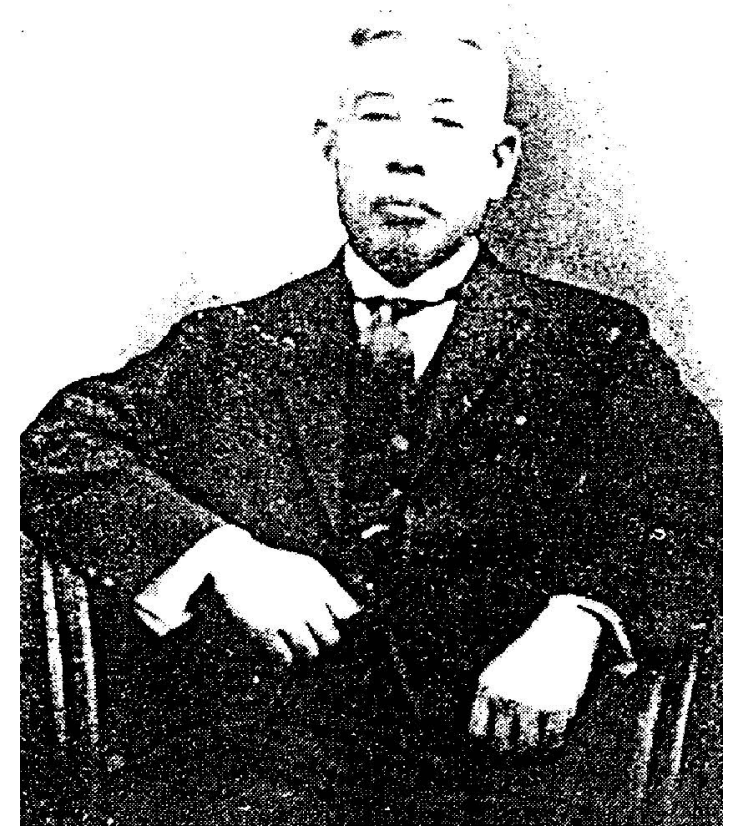

Figura 2. Hachiro Fukuhara e seu busto na entrada da sede da CAMTA. Fonte: HOMMA (2009).

\section{A COLONIZAÇÃo JAPONESA NO NORDESTE PARAENSE}

No dia 24 de julho de 1929, partiu da cidade de Kobe, no Japão, o primeiro navio que transportou os primeiros imigrantes japoneses que se fixaram na Amazônia. O navio Montevidéu Maru trazia 43 famílias, com um total de 189 pessoas. Este chegou no Rio de Janeiro, no dia 7 de setembro. Já no dia seguinte os imigrantes japoneses embarcaram no navio Manila Maru, que chegou em Belém no dia 16 de setembro. Após desembarcarem em Belém, seguiram viagem no barco Tefé até onde hoje se encontra o município de Tomé-Açu, chegando no dia 22 de setembro. Nessa data dava-se início ao processo de colonização japonesa na Amazônia.

A chegada dos japoneses no Brasil e posteriormente na Amazônia não foi um acontecimento isolado ou que se deu ao acaso. A vinda desses imigrantes foi resultado de uma atividade entre os dois países (Brasil e Japão), que visava em comum acordo a política de imigração. O Brasil precisava de mão de obra para que houvesse o desenvolvimento na Amazônia e o Japão necessitava emigrar parte da sua população devido ao excesso de camponeses que estavam vivendo em condições precárias.

$\mathrm{Na}$ Constituição brasileira de 1891 havia uma prerrogativa que dava aos estados o direito de legislarem com respeito à imigração e colonização. A relação entre Brasil e Japão já era muito boa devido ao Tratado da Amizade assinado em 1895, o que foi importante para colocar o Brasil como um ponto de imigração (HOMMA, 2007).

Os japoneses iniciaram o processo de entendimento com o Brasil para que a imigração fosse viabilizada. Em 1915, Kinroku Awazu (1893-1979), veio ao Brasil para estudar as possibilidades de se promover uma colônia japonesa na Amazônia. E assim, com o processo de emigração sendo cada vez mais incentivado pelo governo japonês, começaram a aparecer as Companhias de Imigração. Essas empresas eram privadas, porém subsidiadas pelo governo japonês e tinham o objetivo de negociar com países contratantes de mão de obra. Por meio de uma dessas companhias, deu-se início às negociações entre o governo japonês e o governo do Pará.

Em 1925, o governador do Pará, Dionísio Bentes, recebeu os enviados da Kanegafuchi Bosseki Kabushiki Kaisha (Kanebo), indústria de tecidos no Japão, Yasuhei Ashizawa e Hideo Nakano, do Ministério das Relações Exteriores no Japão, com uma carta do embaixador Hichita Tatsuki demonstrando o interesse dos japoneses em colonizar a Amazônia (HOMMA, 1998 p.4).

Neste encontro, o governador Dionísio Bentes ofereceu aos japoneses as terras situadas às margens dos rios Capim, Moju e Acará. Em 28 de maio de 1925 chegaram em Belém oito técnicos japoneses chefiados por Hachiro Fukuhara para avaliar as terras e decidirem em que iriam iniciar o processo de colonização. Os japoneses deram uma preferência maior às terras situadas às margens dos rios Acará e Moju, devido à profundidade desses rios, o que facilitava a navegação, única via de transporte até Belém na época (CAMTA, 1969).

Em 11 de agosto de 1928, Sanji Muto, então presidente da Kanebo, fundou, com um capital inicial de Y\$10.000.000,00 (US\$4.756.000,00), a Nambei Takushoku Kabushiki Kaisha (Companhia Nipônica de Plantações no Brasil S/A), ficando conhecida como Nantaku, uma espécie de filial da Kanebo, uma vez que a Nantaku tinha como objetivo se desenvolver no Brasil, e esta precisava de uma razão social brasileira (TSUNODA, 1988). Tinha por finalidade: 
Colonização ultramarina; venda e compra de terras; administração de terras adquiridas; e realização de atividades comerciais relacionadas aos núcleos de colonização (CAMTA, 1969 p.8).

Em 13 de novembro de 1928, o governo do Pará concedeu para Hachiro Fukuhara 600 mil hectares de terra em Acará, 400 mil hectares em Monte Alegre e 3 lotes de 10 mil hectares em Marabá. Em 1º de junho de 1929, a Nantaku que tinha como presidente Hachiro Fukuhara - começou a preparar essas terras para os primeiros imigrantes japoneses que chegaram onde hoje está situado o município de Tomé-Açu, em 22 de setembro de 1929.

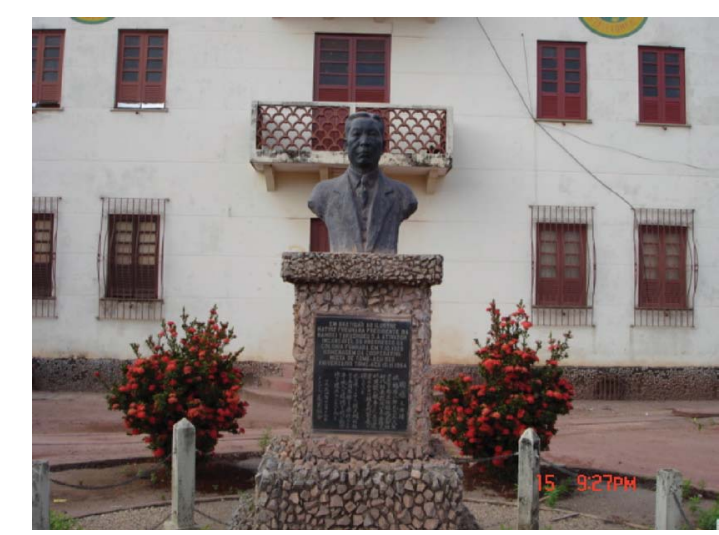

Figura 3. Hachiro Fukuhara e seu busto na entrada da sede da CAMTA. Fonte: HOMMA (2009).
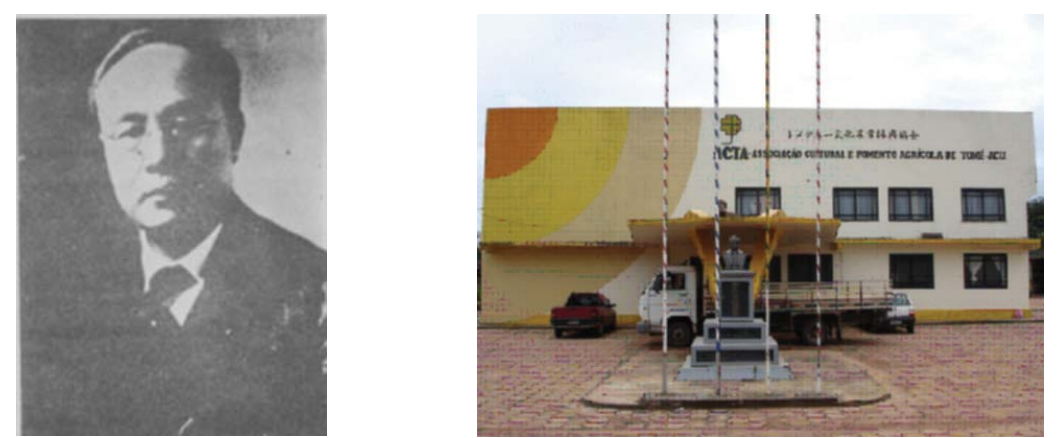

Figuras 4 e 5. Sanji Muto e seu busto na entrada da Associação Cultural de Tomé-Açu. Fonte: HOMMA (2009).

Quando os primeiros imigrantes japoneses chegaram em Tomé-Açu - que ainda pertencia ao município do Acará - encontraram muito trabalho a fazer. Tiveram que labutar bastante para desmatar, construir e plantar. Era o que esses primeiros imigrantes faziam sem folga alguma. As condições eram extremamente precárias.

[...] no começo, pelo que eu me lembro, a gente trabalhava muito, não tinha um domingo pra gente descansar né, não podia parar porque tinha muita coisa pra fazer aqui, tinha que plantar, cuidar da terra porque senão a gente podia perder tudo o que tinha feito de trabalho, então a gente não podia ficar parado né..., não podia (Informação verbal ${ }^{1}$, 2008).

Em dezembro de 1929 chegou a segunda leva de imigrantes. O entusiasmo com a nova terra era grande e a ideia de abundância atraía cada vez mais emigrantes a virem para a Amazônia. Logo depois, veio a terceira leva. O contingente populacional da colônia foi aumentando. As condições econômicas não eram favoráveis, a ponto de fazer com que todos que vieram no quarto navio, voltassem para o Japão.

[...] as vinte famílias da quarta leva acabaram deixando na história da imigração japonesa no Brasil o único caso registrado de debandada total. O que viram em Acará os inquietou, e todos se decidiram pela saída imediata sem mesmo tocar no material fornecido pela Companhia (TSUNODA, 1988, p. 35).

O retorno destes imigrantes japoneses ocorreu devido ao estado penoso em que se encontrava a colônia. Além das condições econômicas desfavoráveis, a malária fazia muitas vítimas e o número de óbitos se elevava a cada instante, sendo que nos primeiros quatro anos foram 51 falecimentos.

[...] Ih! Aqui a malária matava muita gente. Teve uma semana que morreu três. Eu me lembro bem, tinha 5 anos. Primeiro foi o vizinho aqui do lado [o Sr. Hajime Yamada reside no mesmo lugar destinado à sua família quando esta chegou em Tomé-Açu], depois foi o meu irmão. Esses dois morreram um num dia e outro no outro e depois de três dias morreu o filho do vizinho da frente [...] (Informação verbal $\left.^{2}\right)$.

Mesmo com este estado precário, os imigrantes não paravam de chegar. Foram 21 viagens ao todo, trazendo 362 famílias, no período de 1929 até 1937.

As terras em Marabá foram tomadas de volta pelo governo paraense, pois, segundo este, não foi cumprido o contrato por parte dos japoneses e em Monte Alegre a colônia não progrediu e virou abrigo para receber imigrantes nordestinos.

A Nantaku tinha como objetivo a produção de cacau, pois o consumo mundial deste produto era grande e a produção, em igual escala, era pequena.

Hajime Yamada. Entrevista concedida aos autores em 21de setembro de 2008. Idem. 
Como a carência do cacau era de cerca de três anos, outra cultura foi designada pela Nantaku para que os colonos pudessem trabalhar e obterem alguma renda. A cultura do arroz foi a sugerida pela Nantaku, fazendo com que esta também pudesse servir como subsistência para a colônia.

Junto com o arroz, os colonos japoneses plantavam hortaliças para o seu próprio consumo, alimentos que já faziam parte da dieta alimentar nipônica na época. Os imigrantes passaram cada vez mais a plantar hortaliças, pois a lavoura cacaueira não obteve o sucesso que a Nantaku esperava, e vários outros experimentos realizados por esta como: mandioca, extração de fibras e produção de açúcar, seguiam os mesmos rumos do cacau. Diante da necessidade imediata, os japoneses tomaram a decisão de produzirem para sua subsistência tomate, pimentão, berinjela, pepino, e principalmente o nabo - os imigrantes japoneses eram chamados de "nabo" pelos belenenses, quando passaram a vender as hortaliças na capital - foram algumas das hortaliças plantadas por estes primeiros imigrantes.

Após dois anos da chegada dos primeiros japoneses em Tomé-Açu, todos estavam produzindo juntos os mesmos produtos, em meio de diversas dificuldades, foi então fundada a Cooperativa de Hortaliças, em 1931 (ABE, 1959). A diretoria era composta por: Konesuke Takada (presidente), Toshio Sugae (tesoureiro) e Tatsunosuke Murakami (encarregado de vendas). Os japoneses então recorreram ao cooperativismo, sistema econômico que já era conhecido em seu país de origem.

A Cooperativa de Hortaliças abriu em Belém um depósito para fornecer às famílias paraenses os seus produtos. A primeira dificuldade encontrada foi a alta perecibilidade dos produtos, pois muitos estragavam durante a viagem $\mathrm{e}$ eram jogados no rio. Outra dificuldade era o transporte fluvial, feito pelo barco Antonina I (Figura 6), pertencente a Nantaku. O tempo de viagem era de 12 horas na ida para Belém e de 18 horas retornando da capital paraense para Tomé-Açu (HOMMA, 2007).

Mas, a principal dificuldade que os imigrantes japoneses encontraram foi o fato dos paraenses não terem o costume de consumir hortaliças. Somente as pessoas que pertenciam à classe alta é que consumiam legumes e verduras. As pessoas de classe mais baixa nunca haviam consumido ou nem mesmo visto tais produtos. A missão de introduzir aos poucos esse tipo de alimento no cardápio e no gosto dos paraenses era muito difícil.

Tatsunosuke Murakami, o responsável pelas vendas, enfrentando o problema dos baixos consumos, teria que aumentar as vendas para poder obter uma maior receita, tornando-as suficientes para os colonos. E assim foi feito.
[...] a venda somente na banca era insuficiente, e Murakami, lembrando-se então dos vendedores ambulantes da sua terra, contratou vinte vendedores brasileiros, que acrescentaram uma nota nova às ruas de Belém (TSUNODA, 1988, p. 40).

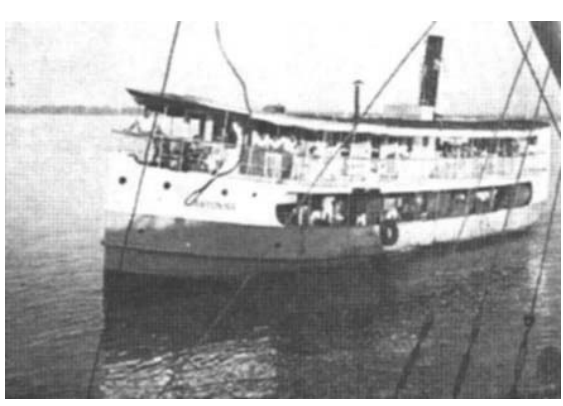

Figura 6. Barco Antonina I.

Fontes: CAMTA (2009) e HOMMA (2009)

A partir desta iniciativa, gradativamente a procura foi aumentando e também aos poucos a produção começava a se expandir. Já no segundo ano, o saldo da Cooperativa de Hortaliças foi positivo (ABE, 1959).

Com o tempo, as hortaliças passaram a ser frequentes na mesa dos paraenses e houve até aluguel de refrigeradores para que aumentasse a conservação das hortaliças e diminuísse a quantidade de produtos estragados.

Mesmo com o aumento das vendas, o preço dos produtos era muito baixo se comparado com as despesas de primeira necessidade que os japoneses tinham que comprar, ainda mais porque os navios com novos imigrantes não paravam de chegar, aumentando a demanda desses produtos.

A colônia passava por dificuldades, em detrimento do que se vendia que era muito barato e o que se comprava era muito caro. A população ia aumentando e foi se tornando naturalmente impraticável a vida num ambiente totalmente inexplorado. Não havia sido ainda descoberto, de modo definitivo, uma cultura agrícola capaz de trazer uma estabilidade à vida. Não havia condição para o auto-empreendimento dos colonos por causa das condições precárias, principalmente sanitárias [...] e para agravar ainda mais a situação, a Companhia (Nantaku) começou a visar lucros imediatos direcionando o interesse mais para o comércio do que para administração da colônia (ABE, 1959, p. 8)

Com a pressão da Nantaku aumentando, e somando isso às condições dos colonos, a relação entre as duas partes, que antes era de grande expectativa, passou a ser tensa e com perigo de ruptura.

A primeira controvérsia entre as partes ocorreu devido ao baixo preço do arroz no mercado. A rizicultura gerava pouco lucro aos colonos e a Nantaku exigia 
$30 \%$, constado em contrato, de toda a produção dos colonos. Estes exigiram a revogação, ameaçando não colher o arroz até que a Nantaku abrisse mão desta cláusula. Esse primeiro incidente foi chamado de "o dissídio dos trinta por cento" (TSUNODA, 1988).

Outro problema entre os colonos e a Companhia Nantaku foi a baixa da produtividade das culturas agrícolas. Não se encontrava nenhuma cultura economicamente viável à região. $\mathrm{O}$ cacau fracassou, assim como os experimentos feitos com outras frutas nas estações agrícolas. Nesse contexto, e com o fim da cláusula dos 30\%, a Nantaku se viu sem recursos para manter a colônia e passou a solicitar ajuda da empresa matriz, a Kanebo, pois o empreendimento encontravase estagnado.

Em 1933, Makinosuke Ussui (Figura 7), coordenador do $13^{\circ}$ grupo de imigrantes que veio para Tomé-Açu, trouxe 20 mudas de pimenta-do-reino de Singapura. O navio teve que parar neste país devido ao falecimento de uma senhora que estava no navio que trazia os japoneses para o Brasil (CAMTA, 2009).

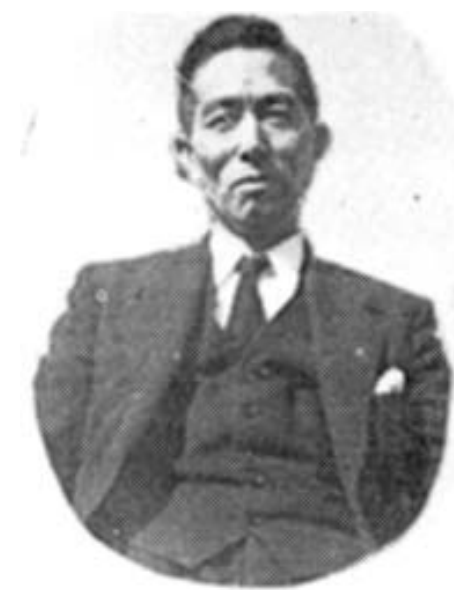

Figura 7. Makinossuke Ussui.

Fontes: CAMTA (2009) e HOMMA (2009)

Devido aos constantes pedidos da Nantaku, a Kanebo mandou o Sr. Mojuro Iguchi realizar um novo estudo na colônia, avaliando-a com o intuito de encontrar soluções para o desenvolvimento da mesma. O resultado do estudo não poderia ser mais objetivo:

O Sr. Iguchi realizou o estudo sobre a gestão da colônia e de imediato contactou os colonos em busca de diálogo para que se chegasse a alguma conclusão. O resultado do estudo foi apresentado no dia 3 de abril de 1935. O Sr. Iguchi constatou que deveria haver uma drástica redução no empreendimento, consistindo em desativação da fazenda agrícola com mais de um mil hectares, abolição do sistema de colonato e fechamento das estações experimentais agrícolas (ABE, 1959, p. 9).

As três medidas colocadas pelo Sr. Iguchi eram de extrema importância para os colonos, que se reuniram em assembleia e apontaram o presidente da Nantaku, Hachiro Fukuhara, como sendo o responsável pelo atraso em que a colônia se encontrava, e que este deveria arcar com recursos próprios para custear a eliminação da crise (HOMMA, 1998). Fukuhara assumiu a responsabilidade:

Devido a erros de administração no passado assumo inteira responsabilidade pela situação caótica atual dos senhores... e, conforme a exigência dos senhores, colocarei à disposição a maior parcela que puder de minhas posses, e me retirarei... (TSUNODA apud FUKUHARA, 1988, p.57).

Hachiro Fukuhara se retirou do cargo e voltou para o Japão. A Nantaku ficou com o sistema de navegação, importação de artigos para vender aos colonos, escolas e hospital que foram construídos com recursos da empresa. O sistema de colonato foi abandonado e tudo ficou a cargo dos colonos. A situação que já não era boa foi agravada. O êxodo de colonos passou a ser constante. Após cinco anos de dificuldades e condições precárias, boa parte dos japoneses começaram a abandonar Tomé-Açu. De 1935 a 1942, cerca de 1.600 pessoas deixaram o Pará, a maioria indo se fixar em São Paulo. Das 362 famílias que chegaram nesses sete anos, 288 abandonaram o Vale do Acará, permanecendo apenas 98 famílias.

Diante desses acontecimentos, a Cooperativa de Hortaliças foi acumulando tempo e os colonos experiência diante desse sistema econômico, formando uma base para o desenvolvimento do cooperativismo na colônia, já que agora a colônia passara a ter autonomia na produção.

Os colonos acrescentaram o arroz - que só era plantado para a subsistência aos produtos comercializados pela cooperativa, que com a nova ordem de produção autônoma passava a se chamar Cooperativa Agrícola do Acará. Esta nascera com três objetivos: "auto-administração efetiva da comunidade; redução de despesas ou austeridade econômica; e fortalecimento do cooperativismo" (KATO, 1994, p. 35).

Constata-se que o foco era o trabalho associativo, em que todos teriam que cooperar com todos. Esta nova cooperativa surgiu diante da necessidade dos colonos que permaneceram na colônia, de procurar desenvolvê-la e assim melhorar as suas condições de vida.

Kato (1994) afirma que a permanência dessas 98 famílias pode ser explicada por questões culturais. No que se refere às questões materiais, o autor aponta 
para a falta de estrutura para a família e a falta de capital como os problemas mais importantes enfrentados pelas famílias que ficaram na colônia. As questões culturais abrangem também a paciência e a palavra dada, com o comprometimento do desenvolvimento da colônia.

Assim, a cooperativa passou a ser o centro da comunidade. Todos trabalhavam voltados para aumentar a produção em perfeita harmonia, buscando a estabilização econômica. Procuravam sempre a venda e a compra nas condições mais vantajosas possíveis, pois agora tinham total autonomia para isso (CAMTA, 1954).

Já nessa época, a pimenta-do-reino estava sendo cultivada em caráter experimental por alguns colonos, pois agora a busca por outras culturas ficara a cargo dos colonos. Mesmo sem haver um melhora significativa na renda dos colonos, o desenvolvimento da cooperativa ocorria dentro da normalidade e o reflexo era visto nas estruturas de produção, fazendo com que os associados acreditassem cada vez mais no auxílio mútuo como uma forma de vencer os obstáculos.

A cooperativa Agrícola do Acará perdurou por sete anos, de 1935 a 1942, quando a cooperativa fora confiscada pelo governo brasileiro, devido à Segunda Guerra Mundial. Os sete anos de existência da Cooperativa Agrícola do Acará foram marcados pela modernização do sistema agrário e uma maior organização da estrutura, e, principalmente, pelo espírito cooperativista incorporado pelos colonos que acreditavam que o cooperativismo poderia ser a solução para a colônia.

A Segunda Guerra Mundial foi o maior conflito da história da humanidade. Envolveu 72 países e foi travada em todos os continentes, direta ou indiretamente. Esta guerra foi travada por dois grupos chamados de Eixo e Aliados. Alemanha, Itália e Japão formavam os países do Eixo, que acreditavam que com o expansionismo e a anexação de diferentes territórios, poderiam alcançar a condição de potências hegemônicas (CROMPTON, 2005).

Vários motivos foram criados para se justificar a invasão por parte desses países. Para invadir a Polônia, o governo nazista (alemão) adotou um discurso de que a raça pura, a ariana, deveria prevalecer sobre as outras, e tendo a Polônia um grande contingente de judeus, começou a perseguição destes, um antissemitismo sem justificativa, que ocasionou uma limpeza étnica que quase acabou com os judeus na Europa. Essa chacina ficou conhecida como Holocausto.
Com a Polônia sendo invadida, Inglaterra e França entraram na guerra em defesa do país invadido. Com isso, dava-se o início da guerra. Em 1941, a então União Soviética entrou na guerra devido a ataques alemães. Depois foi a vez dos EUA, que sofreu ataques aéreos dos japoneses em sua base naval de Pearl Harbor. Assim estava composta a força dos Aliados, que começou a ser montada com a Inglaterra e França, e depois se somou a estes a União Soviética e os EUA (CROMPTON, 2005).

O Brasil entrou na guerra em 2 de agosto de 1942, adicionando suas forças à base dos Aliados. O Brasil possuía bases aéreas e navais na costa do Atlântico, e quando os EUA entraram na guerra, passaram a utilizar essas bases com o propósito de apoio para ataque aos campos de batalhas africanos e asiáticos. Assim, os alemães perceberam que a neutralidade dos brasileiros não era real, e começaram a bombardear os navios mercantes brasileiros e o Brasil entrou para guerra apoiando os Aliados (BUESCU, 1976).

Com a entrada do Brasil na guerra, os japoneses passaram a ser inimigos e isso afetou diretamente a colônia dos imigrantes japoneses em Tomé-Açu. Com o Brasil e Japão em lados opostos na Segunda Guerra Mundial, os japoneses resistentes na Amazônia foram tratados como inimigos. Não só os japoneses sofreram; alemães e italianos - nacionalidade dos países do Eixo - também foram atingidos. Os bens pertencentes às pessoas destas nacionalidades foram confiscados, assim como os documentos, sendo alguns queimados. Esses imigrantes passaram dificuldades, pois os brasileiros se negavam a vender-lhes produtos de primeira necessidade.

A situação piorou quando um navio mercante brasileiro foi afundado por um submarino alemão. A hostilidade do povo paraense aumentou. Casas e comércios pertencentes a imigrantes que vieram dos países do Eixo foram invadidas, incendiadas e até derrubadas. Os imigrantes chegaram a ser apedrejados e passaram a correr risco de morte dia após dia (ABE, 1959).

O governo federal então com o argumento de que iria proteger os imigrantes, confinou os japoneses e outros poucos alemães e italianos em ToméAçu, mas não sem antes tomar posse da Cooperativa Agrícola do Acará. Esta passou a se chamar Colônia Estadual de Tomé-Açu (CETA). Os imigrantes eram restringidos a fornecer e a receber mercadorias. Era um "campo de concentração"3 disfarçado, pois Tomé-Açu era cercado por densas florestas e o único acesso a Belém era pelo rio Acará.

Campo de concentração foi o nome dado às áreas onde os alemães confinavam, torturavam e matavam os judeus. 
Com o confisco da cooperativa, os imigrantes japoneses, que estavam conseguindo melhorar um pouco as suas condições, testemunharam a cooperativa ser administrada por funcionários não comprometidos com a empresa, e, assim sendo, esta ficou praticamente estagnada. A CETA era a responsável pela aquisição dos produtos de primeira necessidade dos imigrantes e pela venda dos produtos da cooperativa à população belenense. No transporte para a execução das vendas e compras, não havia cuidado algum com as hortaliças, estragando-as, e assim o montante da venda era diminuído, e a condição de vida dos colonos começou a piorar novamente.

Neste contexto, alguns poucos colonos compraram as últimas mudas de pimenta-do-reino que restavam no campo experimental, o que aumentou um pouco a renda desses imigrantes (KATO, 1994). Entre os dias 6 e 9 de agosto de 1945, houve os bombardeios em Hiroshima e Nagasaki. O Japão se rendia e era o fim do conflito mais sangrento que a humanidade já viu, que terminou com 50 milhões de mortos e 30 milhões de mutilados (CROMPTON, 2005).

Anunciada a chegada da paz, os colonos que viveram um período cheio de restrições, em que não podiam nem conversar, foram liberados para poderem sair da colônia. A Cooperativa Agrícola do Acará ainda estava em posse do governo, que intermediava as transações. Os produtos produzidos pelos colonos eram vendidos por um valor muito baixo e as mercadorias trazidas para a colônia tinham um valor elevado.

[...] a CETA constituía um obstáculo para o desenvolvimento da colônia, que estagnada vivia a marcar passos, e era urgente a tomada de medida para libertá-la da administração da CETA e recuperar a autogestão sobre a venda de produtos e compras de mercadorias, fazendo a entidade voltar a caminhar por si próprio como antes (ABE, 1959, p. 11).

Com esse objetivo, dezessete jovens ${ }^{4}$, da colônia se reuniram, em novembro de 1945, e criaram a organização denominada "Noumin Doshi Kai” ou União dos Lavradores. Na primeira reunião da União dos Lavradores foram determinadas as diretrizes desta nova empreitada dos imigrantes japoneses:

Permitir ingresso de novos associados; melhorar o processo de circulação de dinheiro; promover negociação com a CETA; melhorar a finança da cooperativa mediante a separação entre as seções de venda e de compra; estudar a possibilidade

Katsuhiro Seki; Shiro Toda; Tadao Sato; Katsumasa Takahashi; Kowashi Sawada; Satoshi Sawada; Fukashi Sawada; Keishi Nagano; Tooru Ikeda; Teruo Sawada; Yoshiharo Nagano; Ilideo Shibata; Torao Hidaka; Hiromu Murakami; Akio Shibata; Noburo Abe e Kozo Fujihashi (CAMTA, 2009 p. 21) de construir um meio de transporte próprio motorizado para a cooperativa (ABE, 1959, p. 16).

O primeiro trabalho feito pelos colonos foi em prol do transporte. A CETA, ainda um órgão pertencente ao governo, fazia o transporte dos produtos da colônia, não satisfazendo o gosto dos colonos, o que impedia o aumento da renda e o desenvolvimento das plantações (CAMTA, 1969). Assim, os lavradores decidiram construir um barco, mas entre esses dezessete lavradores, não havia ninguém que tivesse nenhum tipo de experiência com a construção naval. Ficou decidido então que Keishi Nagano, carpinteiro, iria chefiar a construção e o desenhista seria outro membro da União dos Lavradores, Katsumasa Takahashi. Todos os membros participaram da construção do barco que ficou pronto em sete meses, pesando 18 toneladas. Este era movido por um motor velho de um caminhão desativado. Foi batizado como Universal I (Figura 8) (ABE, 1959).

No dia 18 de fevereiro de 1946, o Universal I, comandado pelos dezessete lavradores fizeram a primeira viagem à Belém. Este acontecimento foi muito comemorado pela União dos Lavradores.

O fato impulsionou estes lavradores para uma nova missão: a de negociar o fim da intervenção estatal na cooperativa e de readquiri-la a favor dos colonos. A negociação foi difícil, havendo diversas conversas para o convencimento das pessoas que comandavam a CETA, mas a paciência e a insistência dos colonos acabou por viabilizar a recuperação da cooperativa. Assim, os problemas foram se resolvendo. O transporte já era feito pela União dos Lavradores, recuperou-se a autonomia na compra e venda de produtos e de materiais, a colônia por inteira apoiava as ações dos lavradores passando-lhes coragem, credibilidade e confiança (ABE, 1959).

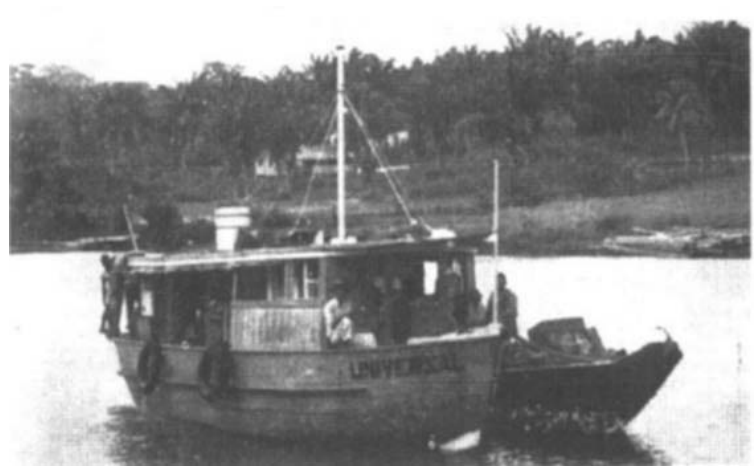

Figura 8. Barco Universal I.

Fonte: CAMTA (2009). 
Assim, com a recuperação da cooperativa os colonos assumiram responsabilidades que antes eram da Nantaku e depois do governo estadual. Várias atividades deveriam ser executadas pela cooperativa, como manutenção e abertura de vias de escoamento da produção, saúde, educação, entre tantos outros serviços internos que favoreceriam os cooperados (KATO, 1994).

Em 30 de junho de 1946, foi feita uma reunião que tinha como assunto principal de sua pauta a oficialização e o reconhecimento da cooperativa administrada pelos japoneses. Era a reconciliação com o cooperativismo, consolidando o associativismo como o princípio centralizador para a nova investida destes imigrantes.

Esta ideia de ter uma cooperativa oficialmente reconhecida nasceu justamente porque, tanto a Cooperativa de Hortaliças como a Cooperativa Agrícola do Acará eram uma sociedade comunitária de fato, mas sem nenhuma proteção constitucional ou legal do governo brasileiro (CAMTA, 2009, p. 29).

A ideia era de uma cooperativa registrada formal e legalmente amadurecia entre os colonos, mas os poucos recursos que estes detinham os impediam de concretizar esta ideia. Entre 1946 e 1947, a pimenta-do-reino começava a se destacar na produção, estando abaixo apenas do arroz e das hortaliças. Em 1947, a produção do arroz estava no valor de Cr\$322.697,00. A produção de hortaliças alcançava a quantia de Cr\$105.279,00. Até 1946, só apareciam nos relatórios da cooperativa os itens arroz, hortaliças e outros. A pimenta-do-reino apareceu no relatório de 1947, e sua produção obteve a importância de Cr\$55.066,00 (CAMTA, 2009). Antes de 1947, a pimenta-do-reino sempre era encaixada no item "outros", mas com a devastação dos pimentais ocasionada pela Segunda Guerra Mundial nos países que eram os maiores produtores de pimenta-do-reino - Malásia, Indonésia e Índia, o preço deste produto teve um aumento de $2000 \%$, o que serviu de incentivo para os colonos japoneses cultivarem essa iguaria.

No final da guerra em 1945, a pimenta-do-reino passou a despontar como uma cultura realmente promissora quando o quilo desse produto subiu de 5 mil réis para 100 mil réis em 1946, isto foi o sinal de largada para a produção de pimentado-reino no Estado do Pará (HOMMA, 1998, p. 69).

Os colonos passaram a ter uma maior prosperidade por meio da pipericultura. Já em 1947, a pimenta-do-reino plantada no Pará representava 10\% da produção mundial e era a terceira maior produção do mundo. Essa iguaria chegou a ser chamada de "diamante negro" da Amazônia, e assim os colonos conseguiam os recursos para a oficialização da cooperativa.
Com a devastação das maiores plantações de pimenta-do-reino ocasionadas pela guerra, o preço dessa piperácea aumentou consideravelmente e os imigrantes japoneses da colônia de Tomé-Açu começaram a plantar a iguaria que gerava lucros substanciais. Essa investida dos imigrantes japoneses na pipericultura acabou determinando um grande poder de acumulação por parte desses imigrantes, e esse lucro que foi reinvestido nos pimentais foi multiplicado, aumentando o poder aquisitivo dos imigrantes japoneses de uma forma rápida e em uma quantidade monetária absoluta muito grande (KEYNES, 1982).

Esse poder de acumulação era alavancado conforme a quantidade de imigrantes adeptos da pipericultura aumentava. Quanto maiores eram as vendas, maiores eram as quantidades de pimenta-do-reino plantadas pelos colonos, sempre trabalhando juntos em busca de uma melhor condição de vida. O efeito multiplicador fez com que os colonos conseguissem capital suficiente para viabilizar a cooperativa.

Os colonos, que recuperaram o poder de compra e venda, transporte e a logística necessária para chegar aos consumidores de Belém, conseguiram em pouco mais de dois anos quantidade suficiente de capital para legalizar os trabalhos associativos que começaram com a Cooperativa de Hortaliças, passando pela Cooperativa Agrícola do Acará e, enfim, pela União dos Lavradores.

Todos os trabalhos em grupos que os imigrantes japoneses fizeram desde quando chegaram na Amazônia em 1929, seria reconhecido e começava assim o maior e mais eficiente Arranjo Produtivo Local (APL) da Amazônia.

Com os recursos obtidos pelos colonos japoneses por meio da pimenta-doreino, juntamente com a autonomia de compra e venda, transporte e produção por eles adquiridos, a ideia da fundação de uma cooperativa oficialmente reconhecida pelos órgãos legislativos brasileiros se tornava perfeitamente viável.

As cooperativas legalizadas tinham proteção do Estado e gozavam de direitos assegurados em leis, e assim os colonos poderiam obter uma maior seguridade para o seu desenvolvimento. Todas as outras cooperativas anteriores deixaram de usufruir as vantagens que eram permitidas às cooperativas oficialmente reconhecidas.

A colônia inteira se uniu para poder se desenvolver e sair do estado arcaico em que se encontrava. Passaram a projetar o futuro nas inúmeras reuniões que passaram a fazer para discutir quais seriam as melhores decisões a serem tomadas (CAMTA, 2009). As providências para oficializar a cooperativa foram executadas 
com arrojo, pois a pimenta-do-reino estava se destacando no mercado cada vez mais, proporcionando todos os recursos necessários para os colonos colocarem em prática os seus objetivos.

Nesse cenário, o consenso geral da colônia se inclinava para a centralização e da unificação em torno da cooperativa, e cada vez mais se consolidava esta consciência da União. Os agricultores, através da autonomia com seus produtos passaram a obter uma renda maior o que fazia com que outros entendessem o espírito de uma associação (CAMTA, 2009, p.30).

Com tanta prosperidade, em 30 de setembro de 1949, foi fundada, dentro dos termos legais, a Cooperativa Agrícola Mista de Tomé-Açu (CAMTA), dando início a uma nova etapa na colonização japonesa na Amazônia (CAMTA, 1954).

Com a legalização da cooperativa, a CAMTA, poderia usufruir de todos os incentivos e benefícios que eram oferecidos pelo governo, fazendo com que a colônia fosse impulsionada de forma mais rápida para o progresso.

No fim da década de 40, a pimenta-do-reino começou a dar sinais de grande rentabilidade. A Segunda Guerra Mundial, que trouxe grandes complicações para a colônia japonesa, fez com que fossem devastados os campos de plantações de pimenta-do-reino dos maiores produtores do mundo, para plantarem comida que serviriam para os soldados japoneses. A produção de pimenta-do-reino antes da guerra era de 93 mil toneladas, após a guerra essa produção passou a ser de 70 mil toneladas. A produção mundial diminuiu e o preço começou a aumentar.

O preço da pimenta-do-reino, entre os anos de 1945 e 1952, não parou de subir. Em 1945, o preço da tonelada da pimenta-do-reino era de US $\$ 220,00$; já em 1948 , o preço da mesma tonelada era de US $\$ 1.368,40$, aumentando mais de 500\% nesse período. O preço da pimenta-do-reino, continuou aumentando a galope. Em 1949 , a tonelada custava US $\$ 2.334,20$ e em 1950 , US $\$ 3.247,60$. Começava aqui a estabilizar o preço da pimenta-do-reino, mas este ainda ia sempre aumentando, não com a velocidade e intensidade dos anos anteriores, mas sempre havia um acréscimo no valor do preço da tonelada de pimenta-do-reino. Em 1952, o preço da tonelada desta iguaria era de US\$3.381,40 (HOMMA, 2007).

Havia pouca oferta de pimenta-do-reino em escala mundial; o preço desta iguaria aumentou consideravelmente. Em apenas sete anos o preço da pimentado-reino aumentou de US $\$ 220,00$ para US $\$ 3.381,40$. Em dólares, esse aumento chegou em torno de $1500 \%$, sendo considerável e repentino. Os cooperados da CAMTA praticamente abandonaram as outras culturas e passaram a plantar a pimenta-do-reino em grande número. A CAMTA passava a operar em sistema de monocultura, pois a piperácea indiana começava a dar lucros muito altos. O número de cooperados aumentava assim como o número de pimenteiras.

Com esses números, a CAMTA passava a ser uma cooperativa de pimentado-reino. A pipericultura era o que gerava desenvolvimento e renda para os cooperados. Em 1955, a produção brasileira já conseguia atender totalmente a demanda interna. No ano seguinte, o governo federal concedeu a CAMTA uma autorização para a exportação da pimenta-do-reino. A primeira exportação teve como destinos a Argentina e os EUA (CAMTA, 1971).

Essa foi a fase de progresso da colônia: a fase do "diamante negro" da Amazônia.

A casa dos japoneses plantadores dessa cultura (pipericultura), de acordo com o grau de dependência e da capacidade de plantio, assumira evoluções, partindo de casas cobertas de cavaco para casas de madeira com cobertura de telha e, enfim, casas de alvenaria [...]. Como símbolo maior de ostentação possuíam veículos, automóveis de luxo estacionados nas residências e percorrendo as estradas rurais entre os plantios de pimenta (HOMMA, 2007, p. 105-106).

Havia um forte ufanismo entre os colonos. A pimenta-do-reino trouxe uma quantia considerável aos colonos. Estes passaram a gastá-lo sem pensar em economizar, isso devido também à inflação galopante da época.

Nas festas não havia "presentes" - era só dinheiro. Tudo era dinheiro. Um dando dinheiro pro outro. Quando um filho de alguém saía para estudar fora, todos davam dinheiro ao menino de presente, não se dava outra coisa a não ser dinheiro [...] (Informação verbal).

A prosperidade na colônia ia aumentando cada vez mais, e no dia 1 de setembro de 1949, já com uma autonomia econômica concreta, Tomé-Açu se emancipa da cidade de Acará, sendo elevada ao "status" de município. Acará arrecadava uma grande parte de sua receita por meio da produção de pimentado-reino em Tomé-Açu, e neste, então distrito, estradas, saúde e educação eram precários e a dificuldade de ir até a sede de Acará requerer algum documento também colaborou para essa emancipação. (SEPOF, 2008).

Assim, com o "boom" da pimenta-do-reino, o dinheiro gerado por esta cultura não foi destinado somente para o luxo dos cooperados. A CAMTA passava a ter outras preocupações. Esta, juntamente com cooperados de diferentes localizações dentro da colônia, passava a investir mais em educação, além de saúde e transporte. Os filhos passaram a não mais trabalhar na lavoura e a maioria desta geração foi estudar em Belém (KATO, 1994). 
O lucro também foi destinado a aprimorar a produção de pimenta-do-reino. Houve grandes compras de maquinaria agrícola e de fertilizantes (HOMMA, 1998). "Era comum a chegada de tratores e materiais agrícolas vindo de São Paulo e trazidos por barcos até a colônia" (KATO, 1994 p. 33).

Desta maneira, a colônia caminhava cada vez mais forte para a monocultura, com grande aumento da produção e da renda, sendo todos os insumos comprados dedicados à pipericultura.

O período de prosperidade da colônia foi de 1947 até 1968. Neste último ano, deu-se uma forte recuperação dos concorrentes asiáticos. Houve uma superprodução na Indonésia, fazendo com que o preço da pimenta-do-reino caísse de US\$750,00 para US\$470,00 em um mesmo ano (1968) (CAMTA, 1971). A monocultura começava a mostrar sua fragilidade aos imigrantes japoneses e logo os cooperados começaram a sentir dificuldades em manter lucrativa a produção de pimenta-do-reino.

Para agravar ainda mais a situação, o fusarium passou a atacar os pimentais. A fusariose, como passou a ser conhecida esta doença, reduz de imediato a vida útil do pé de pimenta-do-reino; com isso, os cooperados passaram a ter pimentais de várias idades para tentar combater a doença (UNE, 1988).

A violenta expansão da fusariose, a partir do fim da década de 60, fez com que os pimentais fossem reduzidos praticamente à produção de subsistência (HOMMA, 1998).

A combinação da queda do preço com a fusariose arruinou as plantações de pimenta-do-reino da colônia, mostrando que a necessidade de diversificação da produção era evidente. A perspectiva de agravamento da situação e a falta de uma política que protegesse a pipericultura fizeram com que os pipericultores e trabalhadores rurais começassem a explorar a policultura.

A Secretaria de Agricultura do Pará passou a incentivar a cacauicultura e a CAMTA passou a buscar sementes híbridas desta cultura na Bahia. Desta forma, o cacau passava a ganhar força na região.

Com a queda do preço da pimenta-do-reino, a CAMTA já estimulava os cooperados a diversificarem a produção, não comprometendo, assim, a sua renda com as flutuações do preço de mercado, e passou a enfatizá-la aos seus cooperados. Com a chegada da fusariose, a diversificação se tornou extremamente necessária.

Noburo Sakaguchi, então diretor da CAMTA, propôs a cultura do cacau como uma alternativa, e com vários incentivos estatais, o cacau começou a ter vários cooperados adquirindo-o para a plantação (CAMTA, 2009).
A Agência de Cooperação Internacional do Japão (JICA), financiou um projeto para reestruturar a cultura da pimenta-do-reino, incentivar a cultura do cacau e fortalecer o plantio de outras culturas como o dendê, seringueira, maracujá entre outras, já visando à diversificação. A JICA liberou para esse projeto a verba de Y\$1.200.000,00 (CAMTA, 2009).

A diversificação evoluiu muito nos anos 80 , indo além da pimenta-doreino e do cacau, aumentando consideravelmente a quantidade de frutas tropicais cultivadas.

Com a queda da pipericultura, o cacau começou a ganhar corpo nas plantações dos cooperados. Foi uma fase de transição, em que os pimentais teriam que dar um pouco de seu espaço ao cacau. As mudanças são complexas, pois misturam um pouco da peculiaridade da situação original com o incremento dos novos traços que está entrando na configuração de uma introdução de uma nova cultura, ou seja, um novo sistema de plantação.

Em Tomé-Açu, o processo de transição teve início com uma nova tentativa de produção do cacau. Com esta cultura voltando à produtividade na colônia, mudanças como o uso do tipo de solo e a forma de plantio teriam quer ser efetuadas. A cacauicultura era uma necessidade para os cooperados que teriam que ter uma resposta devido à crise da pipericultura.

Assim, com a escolha da cooperativa feita a favor do cacau no começo dos anos 70, a Secretaria de Agricultura do Pará deu início ao Programa Inicial do Projeto Cacau (PIPC), e assim oficialmente passou a apoiar a cacauicultura no município de Tomé-Açu, que tentava se reestruturar após a crise da pimenta-doreino (CAMTA, 2009).

Este programa determinava a ativação da cacauicultura em várzeas e ilhas, áreas de pimentais decadentes e áreas que são objeto de programas em desenvolvimento [...], o objetivo básico era recuperar economicamente áreas de pimentais em extinção, não constituindo, portanto, um programa específico de difusão do cacau no Pará, apenas a cacauicultura era umas das opções a pipericultura decadente (COMISSÃO..., 1980, p. 4-5).

Com a criação do Programa de Diretrizes para a Expansão da Cacauicultura Nacional (PROCACAU) por parte do governo federal, houve definitivamente a seguridade do cultivo do cacau em Tomé-Açu. A policultura começava a aparecer nas plantações dos agricultores de Tomé-Açu.

Os cooperados da CAMTA não abriram mão do cultivo da pimenta-doreino por completo, mas cederam um pouco do espaço em que estavam plantados os pimentais para o cultivo do cacau. 
Houve um processo de transição na agricultura em Tomé-Açu. Isso ocorreu devido ao cultivo consorciado ${ }^{5}$, que era uma necessidade para os cooperados, o que fez com que essa ação incidisse em uma queda brusca na quantidade produzida da piperácea, e uma alta considerável na quantidade produzida e nas áreas plantadas com cacau.

A lavoura de cacau estava se expandindo, tendo aumentado sua produção em mais de 400\% no período de 1980-1982, enquanto a pimenta-do-reino reduziu sua produção em $40 \%$; os pimentais foram sendo gradativamente desativados e substituídos.

A década de 80 foi a da tentativa da recuperação para os cooperados da CAMTA. Todos estavam lutando por uma reconstrução e o lema adotado pelos cooperados foi : "A reconstrução depende da autoconsciência de cada um" (CAMTA, 2009). Nessa década, houve uma fusão operacional com a fábrica de sucos da Associação de Fomento Agrícola de Tomé-Açu (ASFATA).

Em meio a esses acontecimentos, houve a elaboração de um projeto que levaria eletricidade à zona rural. A JICA disponibilizou US\$3.600.000,00 para a execução desse projeto. Houve a tentativa de recorrer também a recursos brasileiros, mas a Companhia Elétrica do Pará (CELPA) não pode colaborar financeiramente. Ainda assim, o governo do estado colaborou com US $\$ 100.000,00$, que foram destinados às obras de telefonia (CAMTA, 2009).

O projeto foi executado, com uma rede tronco de $80 \mathrm{~km}$ e as vicinais com $50 \mathrm{~km}$. Havia cerca de 180 subestações, atendendo quase 200 famílias. Assim, nascia a Cooperativa de Eletrificação e Telefonia Rural da Região Geoeconômica de Tomé-Açu em 1989 (COERTA).

Para o funcionamento da eletrificação, a rede tronco deveria ser doada à CELPA, pois se esta não tivesse a posse da rede principal, a eletrificação não poderia ocorrer. Como todos queriam a execução do projeto, assim foi feito, e a rede tronco foi doada à CELPA (SAKAGUCHO, 2009).

Com a CELPA obtendo os direitos sobre a rede tronco, esta teria que pagar 28\% de imposto, cerca de US\$1.400.000,00. Os seus diretores decidiram transformar sua posse em ações, para que esses impostos não fossem cobrados. Essas ações foram avaliadas como $\mathrm{D}^{7}$ e foram repassadas para a COERTA.

Plantio de mais de uma cultura na mesma plantação.

6 Francisco Sakaguchi. Entrevista concedida ao autor em 16 de outubro de 2009.

7 As ações são avaliadas de acordo com seu risco e nomeadas como: A, B, C, D e E, sendo que as ações $\mathrm{A}$ têm o menor risco e as ações $\mathrm{E}$ o maior risco.
Nesse momento, a CAMTA estava com problemas. Mesmo com a administração da fábrica de sucos, que foi transferida da ASFATA para a CAMTA, os rendimentos eram baixos, até que em 1995 e 1996 houve prejuízos, como mostram as Tabelas 1 e 2.

Em 1996, o prejuízo foi de $\mathrm{R} \$ 32.328,85$, e o número de cooperados já era de 118.

Com esse contexto, passou a ganhar força a ideia de dissolução da empresa. Em busca de uma verticalização, foi proposto pela nova diretoria da CAMTA, que assumiu em 1997, a fusão das cooperativas CAMTA e COERTA e das associações ASFATA e Associação Cultural de Tomé-Açu - com a ideia de que os custos iriam diminuir, e assim facilitaria o investimento, melhorando a estrutura em prol dos cooperados. Essa ideia não foi aceita, assim como a nova diretoria não aceitou a dissolução da CAMTA. As associações se fundiram e as cooperativas passaram a funcionar em parceria, a COERTA, que estava bem financeiramente, financiava os recursos de que a CAMTA necessitava para se manter. Não houve a fusão de imediato entre as duas cooperativas porque a CAMTA não estava bem e poderia atrapalhar o desenvolvimento da COERTA (SAKAGUCHI, 2009²). Assim sendo, já em 1997 a CAMTA obteve um saldo positivo em sua receita (Tabela 3).

Tabela 1. Demonstração de resultado da CAMTA - Exercício 1995.

\begin{tabular}{|c|c|c|}
\hline CAMTA Geral & \multicolumn{2}{|c|}{ Valores em R\$ } \\
\hline Discriminações & Receitas e Despesas & Resultado \\
\hline Vendas de Produtos Agrícolas & $1.536 .533,55$ & \multirow[b]{2}{*}{$351.720,20$} \\
\hline (-) Custo de Produtos Agrí́colas & $1.184 .813,35$ & \\
\hline Venda de Sucos & $1.474 .119,48$ & \multirow[b]{2}{*}{$362.312,92$} \\
\hline (-) Custo de Sucos Vendidos & $1.111 .806,56$ & \\
\hline Fornecimento de Mercadorias e Serviços & $1.466 .810,51$ & \multirow[b]{2}{*}{$588.345,95$} \\
\hline (-) Custo de Mercadorias Vendidas & $878.464,56$ & \\
\hline Resultado com Trans. de Prod. Agrícolas & $(+)$ & $30.100,00$ \\
\hline Resultado com Trans. de Sucos & $(+)$ & $45.756,08$ \\
\hline $\begin{array}{l}\text { (-) Deduções da Rec. Bruta (ICMS, PIS, } \\
\text { COFINS) }\end{array}$ & $(-)$ & $223.470,86$ \\
\hline Despesas Operacionais & $(-)$ & $1.157 .432,19$ \\
\hline Receita Financeira & $69.191,56$ & \multirow[b]{2}{*}{$(77.396,68)$} \\
\hline Despesa Financeira & $146.588,24$ & \\
\hline Resultado líquido do Ano & TOTAL & $(80.064,58)$ \\
\hline Perdas do exercício de 1995 & \multicolumn{2}{|c|}{$(80.064,58)$} \\
\hline
\end{tabular}

Fonte: Relatório da Diretoria - Exercício 1995 (1996).

$8 \quad$ Idem. 
Em 1995, houve um prejuízo de $\mathrm{R} \$ 80.064,58$. O número de cooperados nesse ano era de 133

Tabela 2. Demonstração de resultados da CAMTA - Exercício 1996.

\begin{tabular}{|c|c|c|}
\hline CAMTA Geral & \multicolumn{2}{|c|}{ Valores em R\$ } \\
\hline Discriminações & Receitas e Despesas & Resultado \\
\hline Vendas de Produtos Agrícolas & $1.227 .825,00$ & \multirow[b]{2}{*}{$278.315,00$} \\
\hline (-) Custo de Produtos Agrícolas & $949.510,00$ & \\
\hline Venda de Sucos & $2.150 .638,45$ & \multirow[b]{2}{*}{$583.965,05$} \\
\hline (-) Custo de Sucos Vendidos & $1.566 .673,40$ & \\
\hline Fornecimento de Mercadorias e Serviços & $951.182,88$ & \multirow[b]{2}{*}{$381.324,68$} \\
\hline (-) Custo de Mercadorias Vendidas & $569.858,20$ & \\
\hline Resultado com Trans. de Sucos & $(+)$ & 82,09 \\
\hline $\begin{array}{l}\text { (-) Deduções da Rec. Bruta (ICMS, PIS, } \\
\text { COFINS) }\end{array}$ & $(-)$ & $230.633,83$ \\
\hline Despesas Operacionais & $(-)$ & $893.258,77$ \\
\hline Receita Financeira & $30.352,19$ & \multirow[b]{2}{*}{$(152.123,07)$} \\
\hline (-)Despesa Financeira & $182.475,26$ & \\
\hline Resultado Líquido Operacional & Sub-Total & $(32.328,85)$ \\
\hline Resultado com Venda do Imobilizado & $(+)$ & 150,00 \\
\hline \multicolumn{2}{|c|}{ RESULTADO LÍQUIDO GERAL DO ANO DE 1996} & $(32.178,85)$ \\
\hline
\end{tabular}

Fonte: Relatório da Diretoria - Exercício 1996 (1997).

Tabela 3. Demonstração de resultado da CAMTA - Exercício 1997.

\begin{tabular}{|c|c|c|}
\hline \multirow{2}{*}{$\begin{array}{l}\text { CAMTA Geral } \\
\text { Discriminações }\end{array}$} & \multicolumn{2}{|c|}{ Valores em R\$ } \\
\hline & Receitas e Despesas & Resultado \\
\hline Vendas de Produtos Agrícolas & $847.290,00$ & \multirow[b]{2}{*}{$185.110,00$} \\
\hline (-) Custo de Produtos Agrícolas & $662.180,00$ & \\
\hline Venda de Sucos & $1.552 .400,79$ & \multirow[b]{2}{*}{$335.975,21$} \\
\hline (-) Custo de Sucos Vendidos & $1.216 .425,58$ & \\
\hline Fornecimento de Mercadorias e Serviços & $146.688,30$ & \multirow[b]{2}{*}{$146.688,30$} \\
\hline (-) Custo de Mercadorias Vendidas & $\overline{ }$ & \\
\hline (-) Deduções da Rec. Bruta (ICMS, PIS, COFINS) & $(-)$ & $156.724,84$ \\
\hline Despesas Operacionais & $(-)$ & $470.008,21$ \\
\hline Receita Financeira & $27.246,82$ & \multirow[b]{2}{*}{$-69.713,60$} \\
\hline (-)Despesa Financeira & $96.960,42$ & \\
\hline Resultado Líquido Operacional & Sub-Total & $-28.673,14$ \\
\hline Resultado com Venda do Imobilizado & $(+)$ & $43.620,59$ \\
\hline \multicolumn{2}{|c|}{ RESULTADO ANTES DO IMPOSTO DE RENDA } & $14.947,45$ \\
\hline \multicolumn{2}{|c|}{ IMPOSTO DE RENDA SEM GANHO DE CAPITAL } & $-10.905,15$ \\
\hline \multicolumn{2}{|c|}{ RESULTADO LÍQUIDO APÓS O I.R. DO ANO DE 1997} & $4.042,30$ \\
\hline
\end{tabular}

Fonte: Relatório da Diretoria - Exercício 1997 (1998).
Houve um superávit pequeno, de apenas $\mathrm{R} \$ 4.042,30$. Mas, já era um respiro e uma esperança para 109 cooperados que compunham a CAMTA naquele momento. Em 1998, a recuperação foi ainda maior (Tabela 4) . O superávit foi significativo. Foi maior que os prejuízos absolutos somados de 1995 e 1996.

Tabela 4. Demonstração de resultados da CAMTA - Exercício 1998.

\begin{tabular}{|c|c|c|}
\hline CAMTA Geral & \multicolumn{2}{|c|}{ Valores em R\$ } \\
\hline Discriminações & \begin{tabular}{l|} 
Receitas e \\
Despesas
\end{tabular} & Resultado \\
\hline Vendas de Produtos Agrícolas & $2.006 .788,00$ & \multirow[b]{2}{*}{$385.032,00$} \\
\hline (-) Custo de Produtos Agrícolas & $1.621 .756,00$ & \\
\hline Venda de Sucos & $2.444 .836,43$ & \multirow[b]{2}{*}{$734.260,83$} \\
\hline (-) Custo de Sucos Vendidos & $1.710 .575,60$ & \\
\hline Fornecimento de Mercadorias e Serviços & $95.380,17$ & \multirow[b]{2}{*}{$95.380,17$} \\
\hline (-) Custo Sob Serviços & - & \\
\hline (-) Deduções da Rec. Bruta (ICMS) & $(-)$ & $-215.001,09$ \\
\hline (-)Despesas Operacionais & $(-)$ & $-662.481,43$ \\
\hline Receita Financeira & $18.663,59$ & \multirow[b]{2}{*}{$-156.033,85$} \\
\hline (-)Despesa Financeira & $174.697,44$ & \\
\hline Resultado Líquido Operacional & Sub-Total & $181.156,63$ \\
\hline Resultado com Venda do Imobilizado & $(+)$ & $3.224,62$ \\
\hline \multicolumn{2}{|c|}{ RESULTADO ANTES DO IMPOSTO DE RENDA } & $184.381,25$ \\
\hline \multicolumn{2}{|c|}{$\begin{array}{l}\text { IMPOSTO DE RENDA E CONTRIBUIÇÃO SOCIAL } \\
\text { RESUITAOSO }\end{array}$} & $-741,65$ \\
\hline \multicolumn{2}{|c|}{$\begin{array}{l}\text { RESULTADO LÍQUIDO APÓS O I.R. E ANTES DAS } \\
\text { RESERVAS }\end{array}$} & $183.639,60$ \\
\hline \multicolumn{3}{|c|}{ DISTRIBUIÇÃO/FUNDOS/CONF. ESTATUTO } \\
\hline 1-FATES $(5 \%)$ & $9.181,98$ & \multirow[b]{2}{*}{$27.545,94$} \\
\hline 2-RESERVA LEGAL (10\%) & $18.363,96$ & \\
\hline \multicolumn{2}{|c|}{ RESULTADO LÍQUIDO DO ANO DE 1998} & $156.093,66$ \\
\hline
\end{tabular}

Fonte: Relatório da Diretoria - Exercício 1998 (1999).

A CAMTA começava a reagir, em meio às privatizações estabelecidas pelo governo federal na época. Com essa estratégia adotada pelo governo federal, as ações da COERTA tiveram seu valor aumentado significativamente, pois era necessário ter uma quantia mínima de ações para poder concorrer aos leilões das empresas estatais que estavam sendo privatizadas. A COERTA fez um leilão com envelope fechado para poder vender as suas ações.

Nunca se viu tanto movimento aqui em Tomé-Açu. O aeroporto ficou cheio de aviões daqueles monomotor, a cidade tava infestada de caminhonetes e carros, era gente de todo lugar do Brasil. Não tinha hotel na cidade pra tanta gente (Informação verbal'). 
As ações foram vendidas pelo valor de US $\$ 3.800 .000,00$, quase o valor de todo o investimento da cooperativa. Esse dinheiro foi todo investido na colônia e US \$1.400.000,00 foram destinados à ampliação e estruturação da fábrica de suco da CAMTA. A fruticultura começava a obter ainda mais força na produtividade de Tomé-Açu.

Com a ampliação da fábrica de sucos e a construção da câmara fria para manter os produtos estocados, a fruticultura passou a ser o "carro-chefe" da cooperativa, sendo o açaí o produto mais vendido pela CAMTA. A pimentado-reino e o cacau (também a venda da polpa de cacau e não somente a venda da amêndoa) ainda geram cifras expressivas. As exportações de polpas de frutas congeladas passaram sempre a aumentar, principalmente após a capacidade de estocagem frigorífica. As Tabelas 5 e 6 nos mostram a quantidade de variedades de polpas de frutas e os números de exportação destas.

Tabela 5. Demonstrativo de vendas de polpas de frutas em 2007.

\begin{tabular}{l|r|r|r}
\hline \multicolumn{1}{c|}{ Produto } & \multicolumn{1}{c|}{ 2007/ R\$ } & \% de Vendas & Quantidade $\mathbf{k g}$ \\
\hline Polpa Maracujá & $582.185,66$ & 3,90961 & 163.422 \\
\hline Polpa Acerola & $1.050 .442,38$ & 7,05415 & 429.170 \\
\hline Geléia Cupuaçu & $3.246,35$ & 0,0218 & 1.193 \\
\hline Polpa Cupuaçu & $1.312 .415,59$ & 8,8134 & 364.139 \\
\hline Polpa Açaí & $8.413 .657,54$ & 56,5011 & 1.637 .632 \\
\hline Geleada Cupuaçu & $3.811,90$ & 0,0256 & 1.342 \\
\hline Polpa Mix Açaí & $1.146,80$ & 0,0077 & 238 \\
\hline Polpa Açaí Mix Guaraná & $615.062,19$ & 4,13039 & 100.978 \\
\hline Geleada Goiaba & $3.834,05$ & 0,02575 & 1.351 \\
\hline Polpa Abacaxi & $449.495,56$ & 3,01855 & 181.497 \\
\hline Polpa Carambola & $41.917,19$ & 0,28149 & 21.030 \\
\hline Polpa Graviola & $562.202,22$ & 3,77542 & 95.351 \\
\hline Polpa Muruci & $133.413,48$ & 0,89593 & 45.007 \\
\hline Polpa Taperebá & $650.446,48$ & 4,36801 & 159.226 \\
\hline Polpa Caju & $297.883,34$ & 2,00041 & 103.765 \\
\hline Polpa Goiaba & $757.410,99$ & 5,08632 & 245.531 \\
\hline Camu-Camu & 930,8 & 0,00625 & 716 \\
\hline Polpa Cacau & $7.812,03$ & 0,05246 & 2.060 \\
\hline Geléia de Maracujá & $3.442,50$ & 0,02312 & 1.261 \\
\hline Outros & 376 & 0,00252 & 130 \\
\hline Total & $\mathbf{1 4 . 8 9 1 . 1 3 3 , 0 5}$ & $\mathbf{1 0 0}$ & $\mathbf{3 . 5 5 5 . 0 4 0 , 4 0}$ \\
\hline
\end{tabular}

Fonte: Relatório da Diretoria (2008).
Percebe-se nesta tabela que há o início da produção de geleias de frutas. Esses produtos ainda estão em caráter experimental.

Tabela 6. Demonstrativo de exportação de polpas em 2007.

\begin{tabular}{l|r|r|r|r}
\hline \multicolumn{1}{c|}{ País } & \multicolumn{1}{c|}{$\mathrm{kg}$} & \multicolumn{1}{c|}{$\mathrm{R} \$$} & \multicolumn{1}{c|}{$\% \mathrm{~kg}$} & \multicolumn{1}{c}{$\% \mathrm{R} \$$} \\
\hline Austrália & 21.906 & $59.538,26$ & 1,5 & 0,77 \\
\hline Japão & 592.658 & $3.302 .725,06$ & 40,65 & 42,84 \\
\hline USA & 843.448 & $4.348 .059,58$ & 57,85 & 56,39 \\
\hline Total & 1.458 .012 & $7.710 .322,90$ & 100 & 100 \\
\hline
\end{tabular}

Fonte: Relatório da Diretoria (2008).

Japão e EUA são os maiores importadores das polpas de frutas produzidas pela CAMTA. Há um início de exportações para a Austrália, que embora ainda seja pequeno mostra a busca de aumento de mercado por parte da cooperativa.

Nas Tabelas 7 e 8 vemos que a importância da pimenta-do-reino e do cacau ainda são significativas.

Tabela 7. Demonstrativos de vendas de produtos secos em 2007.

\begin{tabular}{l|c|r}
\hline \multicolumn{1}{c|}{ Tipo } & Quantidade/ Kg. & \multicolumn{1}{c}{ Valor/ R\$ } \\
\hline Pimenta Branca & 219.730 & $1.972 .569,30$ \\
\hline Pimenta Preta & 193.952 & $1.224 .672,00$ \\
\hline Cacau & 290.760 & $1.418 .227,00$ \\
\hline Total & 704.442 & $4.615 .468,30$
\end{tabular}

Fonte: Relatório da Diretoria (2008).

Juntos, pimenta-do-reino e cacau foram responsáveis em 2007 por um total de vendas de $\mathrm{R} \$ 4.615 .468,30$, um valor extremamente expressivo para a Amazônia.

As exportações desses produtos também são destinadas ao Japão e EUA, assim como a polpa de frutas, mas os principais importadores dos produtos secos são Alemanha e Argentina.

Nessas tabelas vemos que apesar das baixas, a produção de pimenta-doreino e do cacau não foi cessada, sendo que pode ser vista a importância dessas culturas em Tomé-Açu pelo grande número de instalações que executam o mercado paralelo desses produtos. 
Tabela 8. Demonstrativo de exportação de produtos secos em 2007.

\begin{tabular}{l|l|c|c}
\hline \multicolumn{1}{c|}{ País } & \multicolumn{1}{c|}{ Produto } & Quant. $/ \mathrm{kg}$ & Total \\
\hline Alemanha & Pimenta Branca & 50.000 & $362.175,00$ \\
\hline & Pimenta Preta & 25.000 & $243.375,00$ \\
\hline Japão & Pimenta Preta & 20.000 & $129.210,00$ \\
\hline USA & Cacau & 15.000 & $76.590,00$ \\
\hline & Pimenta Preta & 25.000 & $176.625,00$ \\
\hline Argentina & Pimenta Preta & 73.000 & $433.755,00$ \\
\hline & Pimenta Branca & 179.500 & $1.615 .750,00$ \\
\hline Total Geral & & 387.500 & $3.037 .480,00$ \\
\hline
\end{tabular}

Fonte: Relatório da Diretoria (2008)

A CAMTA continua a tentar diversificar seus produtos e expandir o seu mercado para assim obter um maior valor agregado à sua produção. A industrialização dos produtos agrícolas passará a processar experimentalmente a extração de óleos vegetais advindos do cacau e do cupuaçu. O sistema agroflorestal consorciado desenvolvido pelos cooperados da CAMTA ao longo do tempo em Tomé-Açu atrai a atenção de várias partes do mundo e esse sistema faz com que essa cooperativa aumente a sua produção e desenvolva o seu entorno sempre em harmonia com a natureza.

\section{CONSIDERAÇÕES FINAIS}

A história econômica e social das macrorregiões do Pará estão diretamente relacionadas com a implementação de políticas públicas que não favoreceram a formação de uma sociedade que fosse permeada pela cooperação e coesão, que pudesse romper com as relações verticais entre os atores sociais de todas regiões do estado, principalmente com o clientelismo e a corrupção, características tão presentes na sociedade paraense.

Mesmo com o expressivo crescimento econômico que ocorreu no Pará após a integração do estado ao mercado nacional, na década de 1960, as regiões permaneceram socialmente em péssimas condições. O sudeste paraense, onde se concentram as atividades econômicas que mais contribuem para esse crescimento - mineração e pecuária, também não transformaram em benefícios sociais os resultados econômicos alcançados. Ao contrário, os índices de desmatamento e de violência rural são os piores do Brasil.
Mesmo recebendo apoio do governo japonês nas fases em que a comunidade nipônica de Tomé-Açu enfrentou dificuldades, a continuidade da colônia agrícola na região por setenta anos revela que o ambiente cultural e o grau de associativismo da população japonesa que emigrou e permaneceu no Pará nesse longo período, foi e é fator fundamental para explicar o sucesso do empreendimento associativo de pequenos produtores agrícolas mais bem sucedido da Amazônia.

A CAMTA, ao longo dos 80 anos de imigração japonesa na Amazônia, mostrou que é possível fazer o desenvolvimento socioeconômico, não impactando de forma gritante o meio ambiente. O APL montado pela CAMTA, e a forma de conduzí-lo, agregando valor por meio da modernização, gerando lucros aos cooperados, colaborando com os pequenos agricultores, fazendo com que também tenham um aumento na renda, e mostrando que o cooperativismo, sendo seguido de forma transparente e com comprometimento dos cooperados, consegue fazer com que haja a inclusão social e aumente o bem-estar da população, mesmo que esta esteja localizada em uma região pobre e que enfrente dificuldades de todas as ordens.

\section{REFERÊNCIAS}

ABE, N. História de 30 Anos da Cooperativa Agroindustrial de Tomé-Açu. Tomé-Açu: CAMTA, 1959.

BUENO, E. O Japão e o dilema da imigração. Revista Espaço Acadêmico, n.66, p. 22-43, nov. 2006.

BUESCU, M. Guerra e desenvolvimento. Rio de Janeiro: APEC, 1976.

CAMTA. Comemorativo do $\mathbf{2 5}^{\circ}$ Aniversário de Fundação da Colônia de Tomé-Açu. Tomé-Açu, 1954.

CAMTA. Relatos Históricos da Cooperativa Agrícola Mista de Tomé-Açu. Tomé-Açu, 1969.

CAMTA. Relatos Históricos da Cooperativa Agrícola Mista de Tomé-Açu. Tomé-Açu, 1971.

CAMTA. Relatos Históricos da Cooperativa Agrícola Mista de Tomé-Açu. Tomé-Açu, 2009.

CASTRO, F. 50 anos da Imigração Japonesa na Amazônia. Belém: Funtelpa, 1979.

CROMPTON, S. 100 Guerras que Mudaram a História do Mundo. Rio de Janeiro: Ediouro, 2005. 
COMISSÃO Executiva do Plano da Lavoura Cacaueira. A Cacauicultura no Pará. Belém, 1980.

CURY, V. História da Industrialização no Século XIX. Rio de Janeiro: Editora UFRJ, 2006.

HOMMA, A. Amazônia: Meio Ambiente e Desenvolvimento Agrícola. Brasília: EMBRAPA; SPI, 1998.

HOMMA, A. Imigração Japonesa na Amazônia: sua contribuição para o desenvolvimento agrícola. Belém: EMBRAPA Amazônia Oriental, 2007.

HOMMA, A. A imigração Japonesa na Amazônia (1929-2009): passado, presente e futuro. In: ARAGÓN, L. Migração Internacional na Pan-Amazônia. Belém: NAEA/UFPA, 2009.

IBGE. Estados. www.ibge.gov.br/estados/, 2010.

KATO, M. A Colônia Nipônica no Acará: sua evolução no contexto regional e nacional. Belém: FIPAM, 1994.

KEYNES, J. A Teoria Geral do Emprego, do Juro e da Moeda. São Paulo: Atlas, 1982.

RELATÓRIO da Diretoria - Exercício 1995. Tomé-Açu, 1996.

RELATÓRIO da Diretoria - Exercício 1996. Tomé-Açu, 1997.

RELATÓRIO da Diretoria - Exercício 1997. Tomé-Açu, 1998.

RELATÓRIO da Diretoria - Exercício 1998. Tomé-Açu, 1999.

RELATÓRIO da Diretoria - Exercício 2007. Tomé-Açu, 2008.

SAKAGUCHI, F. Francisco Sakaguchi: entrevista realizada em 16 set., 2009. Entrevistador: Armando Wilson Tafner Junior. Tomé-Açu, 2009.

SANO, R. Imigrantes. Revista dos Trabalhadores, Campinas, n.3, 1989.

SEPOF. Aspectos Históricos e Culturais do Município de Tomé-Açu. Belém: SEPOF, 2008.

TSUNODA, F. Canção da Amazônia: uma saga na selva. Rio de Janeiro: Francisco Alves, 1988.

UNE, M. T. Pimenta-do-Reino no Estado do Pará: uma avaliação dos efeitos da tecnologia sobre a produtividade. Revista Brasileira de Geografia, Rio de Janeiro, v. 50, n. 2, p.75-98, 1988.

YAMADA, H. Hajime Yamada: entrevista realizada em 21 de set., 2008. Entrevistador: Armando Wilson Tafner Junior. Tomé-Açu, 2008.

Texto submetido à Revista em 12.5.2010

Aceito para publicação em 3.11.2010 